\title{
Analysis of one of the Rituals Related to the Category of Birth among Turkmen People from the Mythical Semiotics Point
}

\author{
Seyed Mojtaba Mirmiran ${ }^{1}$, Alaleh Abedy² \\ ${ }^{1}$ Faculty of humanity, Department of Guilanology, University of Guilan,Rasht,Iran \\ 2 Faculty of humanity, Department of Guilanology, University of Guilan,Rasht,Iran
}

\begin{abstract}
Initiation or transition is considered as an important stage or point in human life which involves some certain religious and psychological concepts and is associated with specific ceremonies and rituals which is an implication of Creation. It gives a new identity to a person among a group. These rituals involving three basic stages, birth or beginning of childhood, the stage of adulthood and marriage and then the category of death are held among different Iranian ethnic groups in different ways based on archetypes accompanied with ceremonies indicating passing from one stage to another from the past until now; hence, many rituals related to initiation among different groups can be decoded. So, the hypothesize of this article is according to the fact that, the structure of human mind formed in accordance with archetypes and have a common motif which represented in different forms by signs and symbols in rituals. Turkmen tribe inhabited in the north-eastern part of Iran hold each of these three steps as a symbolic ritual through ceremonies associated with certain services based on mythological themes and archetypes related to Turkmen tribe. This research aim to inquire one of the rituals related to the category of birth among Turkmen tribe from the Eliades stand -point. The data has been collected through field research and the method which is used is descriptive and analytical way. This article intends to inquire mythological signs and symbols used in rituals which have a specific and sacred meaning for the people of Turkmen. Therefore, it is concluded that human beings common notions which is based on early human's religious ideas and demands are turn up in rituals and manifested in different ways.
\end{abstract}

Key Words: Initiation, Myth, Ritual, Turkmen tribe

\section{Introduction}

Ritual is one of the complicated cultural issues and its study in a community helps to more learning about social customs and group behaviors among the people of a society formed based on the archetypes. Some symbolic actions and ceremonies are used in these rituals taken from ancient believes and mythological patterns. It is hypothesized that signs and symbols in rituals manifested in different forms are made according to the structure of the human mind formed in accordance with collective unconscious and have common theme. This research aims to investigate mythic signs and symbols used in rituals which have certain and sacred meanings for the people of Turkmen inhabited in the north-eastern part of Iran. This research aims to investigate one of the rituals related to the category of birth based on field research, psychological - mythological points and descriptive - analytical method according to Mircea Eliade, Joseph Campbell and Carl Gustav Jung. Some symbolic believes are discussed for further explanation; this question also arises that how the interrelationships and sequence of each ritual are expressed based on the archetypes. Generally, rituals mean projection according to group unconsciousness and the hero is someone who is ready for every change and evolution. In the rituals related to the category of transition stage, the hero passes all the ritual stages and actions by accepting an invitation to a journey into the subconscious framework and by receiving guidance from the old wise man and companionship of others and overcoming obstacles through different stages in order for the initiation of a new identity and self-understanding.

\section{Theoretical Framework}

Myth is an indication of sacred narrative and it explains the actions and behaviors which occur in the mythic world related with the eternal period and time. "Mythological ideas showing continuity and immortality of human life truths and stating eternal insights from themes which although they have been changed through time, they have constant and uniform base" (Fotouhi, 2007, p.277). Mythologies create a legitimate argument for tribe rituals, ceremonies and worshipping performances (Barnas, 2013, p.25). Humans of ancient world answer to the 
questions in mind about the world in which they live in according with their reaction to surroundings and the scope of their thought and perspectives and in this way, they create a myth which believe in and hold symbolically in their ceremonies. They believed that the mythological world was creator and beginner of all things. Jung considers the collective unconscious as language of human spirit and their projection manifests the unknown layers of mind and the world around. Eliade also considers the transition stage as religious ritual which is passing from one stage to another accompanied with difficult processes it becomes out of existence realm and relates to cultural domain and it sanctifies human life by renewal and revitalization. According to Jung and Campbell, the person passes all the obstacles in different stages for understanding of condition and new identity like a mystic who seeks sublimity by the help of old wise man; of course, it should be said that in investigating initiation and transition rituals, there are some subsidiary stages such as crooked paths in life which contain different rituals and ceremonies. All these matters help to the mentioned person or hero like praying to plead and beg of God or gods and supernatural powers. For example, according to the human of ancient world or noncivilized man, there is a substantial need to helpers and ritual leaders in the way that passing from one stage to another is impossible without their help or essentially it lacks religious legitimacy. All these steps and entering to them is not possible only by adherence to these rituals. This process which is considered as recognition plays a new role in accordance with a society in which it is to be consolidated. Phenomenology investigates decoding myths and believes during rituals and ceremonies. Mircea Eliade explains phenomenology based on sacred matters playing functional roles in human life and his interpretation of the role and structure of myths is according to the eternal creation pattern, cosmogony and repetition of some examples. He believes that a symbol is an indication of truth and a divine manifestation shown in rituals, in his opinion being in eternal moment and stage is considered as religious experience for human. Unconscious patterns consist of ties between religious principles which are manifested through experience (Jung. B, 2013, p. 23). The divine issues help humans such as mythic heroes to achieve evolution, because, human is always captured by eternal intuitions created in the universe. (Eliade, 2010, p.404). Human settles in a period and place better than this world by holding these rituals and he gets rid of mundane affaires and perceives the great period and time (Eliade, 2010, p. 401).

\section{Turkmen}

Turkmen tribe consisting of Turkish and Mongol races inhabited in north-eastern part of Iran is divided into three major groups: Teke, Coghlan and Yomut . The geographical area occupied by Yomut starts from Turkmen harbor and Aqqala and Gonbad and ends at Marvah hill (refer to Goli, 1988, p. 40-66). They spend time and live up by pastoral occupation. Turkmen people hold certain ceremonies and rituals in every stage of transition.

\section{One of the Rituals of Turkmen People Related to the Category of Birth}

In the past, pregnant women were giving birth in a tent by the help of native midwife "Govouk Ana" (grandmother) and presence of an old and experienced woman. By starting first pain of childbirth, when the child is born, woman relatives and she were going to see "clergy" with an experienced woman for having a comfort and safe childbirth. When child has birthed, parturient was sitting in front of lucky star and against unlucky one. Then some actions were performed for giving birth such as blowing in the ewer or frightening parturient by her mother-in-low. But when the childbirth was difficult, some ceremonies were performed for comfort childbirth such as banging on a mortar, firing gun or frightening her by wild animals such as wolf. In some cases, "her mother-in-law enters to the tent with a sword and passes over her legs for three times saying "Gurt Galdi" (wolf is coming). Of course the pregnant woman is in lying position (Matoufi). At the same time, another woman put three pieces of stones into a pot containing boiling water. After the birth, a chain or hobble was fasten to mother foot and then mother was drinking the boiling water in pot. Immediately, midwife was cutting the umbilical cord of the child. For doing it, she was asking permission from mother relatives for three times and then she was washing the child with water and salt. Afterwards, the child was given to native clergy to whisper in his ear call to prayer, word of God and his chosen name. The clergy wants sincere wishes for child and her parents. Women cover child face with a soft cloth for forty days. Also, according to the baby's sexuality, some objects were hung on the entrance such as archery, ram's horn, spindle, scarf and etc. A celebration was held at the same day and some gifts were given to midwife by baby's family and those who were present when childbirth. 


\section{The Study of Some Symbols and Believes}

\subsection{Believing in Lucky and Unlucky Star}

Believing in lucky and unlucky star has been driven from astrological science established in human mind as patterns based on natural experience of early humans with religious motifs. They play important roles in their lives. In some cases, they have desirable and at other moments have undesirable effects. The universe has shown its celestial objects to human. The sky was considered as a sacred thing from mythological and early humans worldview and it was the place of gods. According to Bundahishn, the sky was first created and then all creatures were created in the sky (Dadegi, 2011, p. 40-41). Eliade explains that observing the arch of heaven and motivating a religious experience is its secret of superiority (Eliade, 2006, p. 57). Regarding symbolism category, he states that: "the sky is a symbol of cosmetic system and the divine God is the supporter of stability of cosmic weights and preserver of human societies balance" (Eliade, 2007, p. 76). There are two groups of Ormuzd and devilish stars in the sky in Zoroastrian literature. Each of them can be praised or criticized according to their function and influences the human destiny (refer to Bahar, 2012, p. 60-66). Time is considered a holy category by early people. Eliade states that "time acquires a new domain which can be known as the realm of holiness manifestation and because of its advantages, it acquires not only a particular rhythm but diverse and contradictory divine decrees (Eliade, 2000, p. 366). According to these rituals among Turkmen tribe, Tangery; the God of sky or the father God observes all behaviors. Lucky stars with supernatural grace are the helpers which protect heroes by their blessing forces in a way that the hero avoids dangerous forms which are considered as obstacles for the hero.

\subsection{Stone}

Here, stone is a symbol of fertility and productivity. A rough stone is considered as a passive and rubble substance. When it is formed by human, it will be unclean but when it is formed by divine and spiritual powers, it will be holy and sacred. When a stone is formed by divine powers, it is an indication of turning a devilish spirit to a holly one (Shovalie, $3^{\text {rd }}$ Volume, 2003, p. 634). In Sami traditions, human is born from stone, even some considers that the Jesus is born from stone. According to Chinese, $\mathrm{Yu}$ and his son were born from stone (Shovalie, $3^{\text {rd }}$ Volume, 2003, p. 431-634). According to someone who considers everything alive, objects have spirits and they protect the hero and guide him. Based on this reasoning, even the stone is alive. Since the stone is part of a mountain, in mythic human point of view, it is an indication of divine issue. He does not consider it as a solid and spiritless substance but as a material which is manifestation of spirit, firmness and holy life. Jung also defines stone as a symbolic and great material, because it is the place of gods and holy spirits and it was used in graves, determination of boundaries and making valuable religious objects (Jung, 2013, p. 353). According to Eliade, in early human opinion, stone is manifestation of a holy thing and something rather than the stone itself and it is a magic substance. In some of cultures, stone is a symbol of fertility, a rest and comfort place for dead souls and their spirits, center of the universe, holiness and human supporter (Eliade, 2010, p. 215230). The sun is a god that is born from stone (rock) (Hinnells, 2012, p. 124).

When a stone boils in water, it is a symbol of creation which possesses divine and holy origin in addition to curative characteristics. In other words, its effectiveness and properties is not because of its own power, but because of its origin and source. It is mysterious and a sign of divine origin showing "empathy and sympathy" between the universe and creatures. Materials and tools are sacred powers and considered as reservoir of those forces (Eliade, 2010, p. 224). In this way, a kind of unconscious identity is created between alchemist spirit and alchemy. In other words, a confined and transformative spirit is built. It influences everything dominated it. By releasing the spirit imprisoned in stone and by its boiling in round pot which is a symbol of womb, it should give birth to a son of a philosopher or miracle stone and in this way, "immortal water" is created (refer to Jung, 2013, p. 300-321).

\subsection{Washing in water and salt}

Washing in water is a symbolic ritual of different tribes in ceremonies related to initiation. Water is the essential liquid of life and material of physical and spiritual birth and a means of ritual purification. In Tibetans' rituals, water is the symbol of allegiance by mystic (Shovalie, $1^{\text {st }}$ Volume, 2003, p. 3-8). The alchemist considers water as Acquacentra, organic mercury and moonlight juice (Jung. B, 2013, p. 107). Salt is one of the important materials in rituals because of its cleansing and preserving features in daily life of Nippon (Shovalie, $5^{\text {th }}$ Volume, 
2003, p. 449). Salt and soul are closely related, salt does not just mean the center of earth, but it is considered as a metaphysical substance. Therefore, it is used in most of rituals related to washing and baptism. Baptism rituals can be compared with symbolic burial and entering through a hole of a stone and underground tunnel (Shovalie, $4^{\text {th }}$ Volume, 2003, p. 362). Eliade believes that diving in water is a kind of apparent termination and repetition of cosmic creation and apparent manifestation. It also increases potential capacities of life (Eliade, 2012, p. 173). Also, the water is the base of creature manifestation and the earliest liquid of life. Jung believes that water is drawn out of the rock and it is spiritual life of Anima (Jung, 2013, p. 296). In traditions mentioned in Bible, life is a corrupted phenomena and every natural impulse is followed by sin, unless it is baptized or circumcised (Campbell, 2013, p. 79). It is observed in Yashtha that the individuals who want to be purified wear a white garment in ritual purification of "Nashve" (quoted by Mazdapour, Shayest Nashayest, p. 50). Apām Napāt is the God of the waters and it means the child of water in Avesta. He lives in depth of water and distributes water. It is brilliant like Amesha Spenta and keeps luminosity and brightness between waters (Amuzgar, 2009, p. 22). The rituals of head and body washing is accompanied with the concept of immortality in Shahname such as ceremonies related to baptism of Esfandiar and the category of brazen-bodied performed by Zoroaster (Ferdowsi, 2007, p. 904). The presence of Zoroaster, a messenger of God, means an interval between human being ad gods, importance of a wise man who honors his student, washing child with water and salt which is incorruptible substance and pray of clergy as a wise man and accepting the child as a new member. The ceremonies of baptism is done in Brazil too and it is continued with some sentences saying that the baby is devoted to her real mother and in this way devil deeds of his parents is forgiven (Eliade, 2010, p. 192). This ritual has been done in Christianity in order for forgiveness regeneration.

\subsection{Banging on a mortar, firing gun}

Banging on a mortar and firing gun can be studied from two perspectives such as medical-magician and discharging the evil forces. Its relationship with the category of magician is one of the significant features of primitive rituals. The magic was considered by primitive humans as coordinating natural elements or divine forces. Mortar is a symbol which has an important role in mythology such as pot. Mortar, the water of life and other examples have been observed in songs and their sexual symbolism is compared according to their cosmic nature. The mortar is compared with womb in the songs (Shovalie, $5^{\text {th }}$ Volume, 2003, p. 525). Banging on a mortar is a magic of similarity; it means that everything in the world makes its own similar one (Fraser, 2009, p. 81). In fact, banging on a mortar which is a symbol of eternal womb is helping to the childbirth. Homeopathic magic as an imitative force for facilitating childbirth and blessing is used among primitive tribes such as Davak people. In the way that when the mother suffers from childbirth pain, a magician makes easier the process by shaking the mother's body. At the other hand, another magician tries to facilitate this process by a way that seems absolutely unreasonable. In fact, she pretends that she is a woman in labor. A huge stone is tied around her stomach indicating a child in his mother womb. She listens to the orders which her colleague yelling from the room and moves her un-real baby by exact imitation of real baby movements until the child is born (Frazarr, 2009, p. 90).

Banging on a mortar and firing gun can be studied from another point of view such as discharging evil forces and spirits. In some cases such as cosmic creation and timelessness, people are placed in forbidden conditions. Of course, according to early human believes, the woman is carrying evil and unclean forces after childbirth (Gymen, 1996, p. 154) and they are vulnerable against evil forces and want to be protected. Therefore, they make noises for discharging evil forces and spirits. It is common among Koryak tribe that they hold a celebration after winter and if there was a Shaman among guests, it searches the whole house and beats drum and in this way spirits and ghosts would escape (Frazar, 2009, p. 606). In many rural areas in Iran, people are banging on wash-tubs to discharge evil spirits by making noises. The insecure feeling about surrounding, leads in primitive ideas and resorting to childish projection (Bettleheim, 2013, p. 64).

\subsection{The number Three}

Numbers are not considered as real and reasonable objects in mythological point and each number enjoys a certain interpretation and inherent power which can be transferred to everything related with it. The number three is an important symbol, because it involves some certain natural forces. It is a symbol of creation and growing force and is considered as a complete figure. Because it involves the beginning, center and ending of "all" words. Its power is universal and involves three natures the sky, the earth and the seas. It is a celestial 
number and the central point of balance. Combination of three materials such as Sulfur, Mercury and salt is a symbol of spirit, soul and body (Cooper, 2000, p. 26). Three intellectual and spiritual markers are in connection with God, the universe and human being. In Hinduism, God is manifested in three forms of Brahma, Vishnu and Shiva. Nomadic Arabians were selecting three portions or arrows for making a decision. It indicates a religious and magical character such as Good Thoughts, Good Words and Good Behaviors. In some part of Avesta, the purification procedure was performed three times (Shovalie, $3^{\text {rd }}$ Volume, 2003, p. 664-665). Also, the divisions in Iran ancient culture in which all of them are in three parts; such as division of the world into three parts according to time; three millennia, or division of mythic roles such as triple roles of Jamshid; his global domination which is for Mehr, his kingdom which is devoted to Fereydun and his heroic royalty which is given to Garshasb (Amuzgar, 2009, p. 55). All good things are triplets. Bruno Bettleheim considers the number three as three aspects of the mind; body, I and superman (Bettleheim, 2013, p. 128).

\section{Analysis of Rituals}

In rituals and ceremonies related to initiation, passing from the stages that have mythic origins and are considered as repetition of eternal journey of mythic heroes is an essential category. The child is a hero who enters to these stages which are indicators of religious and serving ceremonies and is trying to reach ideal perfection by help of others and passing from obstacles beyond the realm of time and place. The unconscious process related to the hero changes through a symbolic journey and he makes a relationship by his unconscious nature (Jung, 1989, p. 90). Campbell believes that the man is always trying to achieve evolution through transition process. He leaves the daily life in this process and starts an adventurous journey into the realm of supernatural wonders. He faces with fabulous forces and achieves a decisive victory. The hero bestows grace and blessing to his followers during this mysterious journey (Campbell. A, 2013, p. 40). The journey starts by an invitation and help of supporting and unseen forces from the tent (Turkmen house) with its apparent sacred and holy features. According to the mentioned ritual, the pain of mother is a sign of invitation to a journey. The mother and child pray for discharging evil forces and spirits and asking supporting from all creatures, because suffering and disasters are caused by interference and influence of mysterious reasons in mythic point of view (Shayegan, 2004, p. 133). Then, the hero passes the first stage by the help of midwife or the old wise man. Individuals such as midwife and clergy are reminder of archetypes like the old wise man in Jung point of view. Divine characters are symbolic manifestations of perfect ones who possess valuable nature and force in a way that he ignores from himself and forgets himself (Jung, 2013, p. 164). "The old wise man is a symbol of father or spirit and unconscious spiritual nature.

The archetype of the human soul emerges when he needs insight, decision making and planning. The old wise man means thinking, identification, insight, wisdom and vigilance. He is also an indicator of moral features which are observed in his behavior such as good will and readiness for help and assistance (Moreno, 2013, p. 61). The man always encounters with saints or supernatural forces in mythic narratives which play the role of intermediaries between supernatural forces and the human (Strauss, 2001, p. 36). Praying is another way of resorting to supporting forces through transition stages, because prayer is one of the archetypical supportive forces which are often evident but they are not necessarily tangible. As mentioned, the helpers perform some actions for comfort childbirth and discharging evil forces such as traditional medicine, magic-medical affairs, banging on a mortar, firing gun, entering of the husband to the tent by a sword and crossing over her legs for three times, false representation for receiving fertile and productive forces against opposition ones and fastening the mother's legs because of maintaining the soul in her body. The sword is a metal and since the metal is a sacred material and a tool for eternality, it is used for imprisoning or destroying evil forces and avoidance of obstacles. As at the end of the world, this element purifies the creation of Ormuzd from devilish forces and becomes eternal by destroying the death and devil. The hole attacked by devils is purified by this metal. The world becomes immortal with no death (Dadegi, 2011, p. 148). According to Iranian believes, putting a piece of iron metal, gun and sword in parturient room protects her from evil spirits (Hedayat, 1999, p. 39). This operation is performed for three times in order for using the creative force of this number for renewal and revitalization. The woman is protected against evil spirits and forces by fastening her feet. String, yarn and cord is still used in the process of childbirth against disease and evil spirits (Eliade. B, 2012, p. 127). In China, a cotton string is tied to patient's arm for removing spirit and remains on her arm until it is worn (Fraser, 2009, p. 233). All these operations are for removing evil forces and are considered as religious manifestations. As Durkheim believes, 
these are collective manifestations indicating collective realities and are the result of social realities, the way of living and human collective desires; in other words, religious rituals are practical methods created at the heart of joined religious groups for stimulation and recreation some of psychological states of these groups (Durkheim, 2003, p. 13). The first stage of transition starts by the category of birth which is a kind of separation stage. The processes before separation can be compared with the story of Jonah in Islamic tradition. In the way that, after three days and nights, God orders the fish to bring him to land (Sattari, 2000, p. 7). Then the baby is separated from his previous cosmic universe and enters to a new world by cutting his umbilical cord. Because the cosmos itself, is considered as a tissue or woven material. For example, in Hinduism the air has created the universe by connecting this world to another world and all creatures (Eliade, 2012, p. 129). The hero is placed in sacred eternal chaos by washing in water and salt by the wise old man. Because the primitive man comes back to mythic times through rituals. In other words, he is placed in eternal womb or crocodile belly and he gets a new life by passing this stage. Afterwards, he finds legitimacy in new world by the help of another wise man (clergy) who whispers creation songs and words to his ear. In this way, the child becomes familiar with the world and ethnic cultures through these ceremonies. He gives validity to the child by announcing this point that his entity is in accordance with mythological patterns (Eliade, 2012, p. 53). Then, he is confined by covering his face for forty days; the number forty has a mythic meaning in Jewish tradition. The children of Israel were wandering for forty years. Jesus went to desert for forty days after baptism by John (Campbell, 2013, p. 206-210). In other words, the hero travels to unconscious place, the origin of whole universe after baptism. Then, some rituals are holding and some foods are cooked for removing evil spirits. In this way, they offer a sacrifice before gods and evil forces and protect the hero. This ceremony can be compared with Eucharist in Christianity which is a kind of scarification and connection between body and soul. The rebirth and baptism is performed in Eucharist and then the priest mentions the changing of nature by some praying. All the creatures are released and find a new identity (Jung. B, 2013, P. 380). The ancient Egyptians were using of cows for removing the evil forces and spirits of their territory and then they were selling them to Greeks or throwing them in rivers (Fraser, 2009, p. 613). In this way, the child personality which was temporally hidden in collective unconscious is recovered by certain ceremonies and rituals.

\section{Conclusion}

Certain rituals are observed in investigating the rituals related to the category of birth as one of the initiation ceremonies among Turkmen tribe. Of course each of them has a specific interpretation based on their collective unconscious. The evaluation of mythic insights and their reaction to sacred phenomena is a valuable point, because the myths are considered as symbols of unconscious nature and way of religion perception. According to Eliade, religion is human reactions to what are considered as sacred ones. They are manifested by different rituals because rituals and every reasonable and significant act is the repetition of mythic patterns and put the human in magical-religious trends of time (Eliade, 2010, p. 401). According to the mentioned ceremonies, the child as a hero passes all the rituals and initiation stages by help of the old wise man and removing evil spirits and experiences his rebirth by passing from water and symbolic meanings.

In mentioned ritual in this research, all these symbols and ceremonies were an indication of coming back to eternal time and enjoying inherent nobleness before of human birth. For this reason, the myth of creation and eternal chaos are appeared and manifested; because, religion is a kind of second womb and a place that in which the human is guided into adolescent and evolution of cognitive development. It means that "it makes a man a self-motivated and independent" (Campbell, 2013, p. 91). The mythic period is recovered by imitation of mythic hero behaviors (Eliade, 2010, p. 372) and the child comes out from the mundane realm and is placed in a sacred domain beyond the time and place. In this way, he achieves to a mental perception of new stages in his life.

\section{References}

[1] Gh.Amuzgar, "Tarikh-e Asatiri-e Iran (History of Iran Myths)" Tehran: Samt, 2009.

[2] M. Eliade, "Moqaddas and na-moqhaddas (The Sacred and the Profane: the nature of religion", translated by Nasrollah Zanguei, Tehran: Soroush, 2008.

[3] M. Eliade, "Resaleh dar Tarikh-e Adian (Trait d'histoire des religions)" translated by Jalal Sattari, Tehran: Soroush, 2010.

[4] M. Eliade, “Osture va Vagheiat, translated by Mani Salehi Allame”, Tehran: Pars Book, A, 2012.

[5] M. Eliade, Mircea, "Tasavir va Nomadha, translated by Kazem Mohajeri”, Tehran: Pars Book, B, 2012. 
[6] J. Boyer Noss, "Tarikh-e Jame Adyan, translated by Aliasghar Hekmat", Tehran: Scientific \& Cultural Publications, 2013.

[7] B. Bettelheim, “Afsoon-e Afsaneha”, translated by Akhtar Shariat zade, Tehran: Hermes, 2013.)

[8] F. Dadagi, "Bundahishn", a report of Mrhrdad Bahar, Tehran: Toos, 2011.

[9] E. Durkheim, "Sovar-e Ebtedaei-e Hayat-e Mazhabi", (Primitive Nader Salarzadi Amiri, $1^{\text {st }}$ Volume, Tehran, 2003.

[10] J. Sattari, "Jahanshahi-e Osture", works of L. Strauss, Malinowski, A. Crop, Gan Kazno, Carmen L and Abraham, 1998.

[11] "Pajuheshi dar Gheseye Younes va Mahi”, Tehran: Marka, 2000.

[12] D. Shayegan, "Bothaye Zehni va Khaterat-e Azali", Tehran: Amirkabir, 2004.

[13] J. Chevallier, J.Cheerbrant "“ Farhang-e Nemadha”, translated by Soudabe Fazaeli, Tehran: Jeeyhoon, vol.1,2,3,4,5. 2009.

[14] M. Fotouhi ,“Belaghat-e Tasvir”, Tehran: Sokhan, vol.1, 2007.

[15] A. Ferdowsi " "Shahname” bar asas-e Noskhey J. Mohl, Tehran: Elham, 2007.

[16] J.G. Frazar,"Shakheye Zarrin", translated by Kazem Firoozmand, Tehran: Agah, 2009.

[17] J. Campbell, "Ghahreman-e Hezar Chehre", translated by Shadi Khosropanah, Mashhad: Gol-e Aftab, A, 2013.

[18] "Ghodrat-e Osture", translated by Abbas Mokhber, Tehran: Markaz Publications, B, 2013.

[19] J.C. Cooper, "Farhang-e Mosavar-e Nemadhaye Sonnati", (An Illustrated Encyclopedia of Traditional Symbols) translated by M. Karbasian, Tehran: Farshad, 2000.

[20] A. Goli, "Tarikh-e Siasi Ejtemaei Turkmenha", Tehran: Elm, 1987.

[21] D. Guillemin, "Din dar Iran-e Bastan”, translated by Roya Monajem. Tehran: Fekr-e Ruz, 1996.

[22] L. Strauss, "Osture va Tafakor-e Modern", translated by Fazel Larijani \& Ali Jahan Poulad, Tehran: Farzan Ruz, 2001.

[23] A. Matufi, "Tarikh, Farhang va Honar-e Torkerman", Tehran: Tehran University Press, vol. 1, 2, 3. 2004.

[24] A.Moreno, "Khodayan va Ensan-e Modern", translated by Darush Mehrjooei, Tehran: Markaz, 2009.

[25] S. Hedayat "“Farhang-e Amyane Mardom-e Iran", Tehran: Cheshme Publications, 1999.

[26] J. Hinnells, J. Russel, "Shenakht-e Asatir-e Iran", translated by Bajlan Farrokhi, Tehran: Asatir, 2010.

[27] C.G. Jung, "Chahar Surate Mesali”, translated by Parvin Faramarzi, Mashhad, 1989.

[28] "Ensan va Sambolhayash (Man and his Symbols)" translated by Mahmoud Soltanie, Tehran: Jami, A, 2013.

[29] “Ravanshenasi va Kimiagari”, translated by Mahmoud Behforuzi, Tehran: Jami, B, 2013. 